\title{
Insights Into The Broad Antibacterial Spectrum of Bacteriocin Isolated From Probiotic Lactobacillus Fermentum LMEM22 Strain
}

\section{Debashis Halder}

University of Gour Banga, Malda-732103, India

Manisha Mandal

MGM Medical College, Kishanganj-855107, India https://orcid.org/0000-0002-9562-5534

Nishith Kumar Pal

NRS Medical College and Hospital, Kolkata-700014, India

Shyamapada Mandal ( $\sim$ samtropmed@gmail.com )

University of Gour Banga, Malda-732103, India https://orcid.org/0000-0002-9488-3523

\section{Research Article}

Keywords: Probiotics, Lactobacillus fermentum, Bacteriocin, Antibacterial activity, Indicator bacterial pathogens

Posted Date: July 14th, 2020

DOl: https://doi.org/10.21203/rs.3.rs-41220/v1

License: (9) This work is licensed under a Creative Commons Attribution 4.0 International License. Read Full License 


\section{Abstract}

This communication aims to validate the probiotic attributes of the Lactobacillus fermentum LMEM22 strain, safety profiling, 16S rRNA gene sequence analysis, and bacteriocin characterization. The bacteriocin of $13.1 \mathrm{kDa}$ (based on the glycine-SDS-PAGE analysis) was isolated from L. fermentum LMEM22 curd strain (NCBI GenBank with accession No. MH380182), the identity for which was confirmed by $16 \mathrm{~S}$ rRNA gene sequence analysis. The probiotic properties and safety profiles were authenticated in vitro systems. The zone diameter of inhibition from the L. fermentum LMEM22 bacteriocin action, following agar-well diffusion, ranged $19-23 \mathrm{~mm}$ and $17-24 \mathrm{~mm}$, respectively, for gram-negative and gram-positive bacteria. On enzymatic treatment with proteinase $\mathrm{K}$ and trypsin the bacteriocin lost the bacterial growth inhibition capacity, and it was found insensitive against a-amylase action, authenticating its proteinaceous nature. The $y$-haemolytic $L$. fermentum LMEM22 strain, for which gelatinase and DNase activities were negative, had tolerance to high sodium chloride concentration range (2 - 6.5\%), low pH $(2-4 \%)$, and bile salts $(0.125-0.5 \%)$. This study, thus, authenticated the probiotic attributes of $L$. fermentum LMEM22 strain for safe consumption by the people, and the usefulness of bacteriocin isolated, as a valued protein antibiotic for the prevention and treatment of multidrug resistant bacterial infection.

\section{Introduction}

The antagonism of probiotic LAB (lactic acid bacteria) strains against human pathogenic bacteria has been reported to be due to their capacity to produce hydrogen peroxide, organic acids, such as lactic acid, and bacteriocins. The bacteriocins are antimicrobial peptides of low molecular weights and produced by gram-negative as well as gram-positive bacteria (Usui et al., 2012; Bosak et al., 2018); however, those produced by LAB remain the most valuable compounds in food and medicine (Dobson et al., 2012), because the majority of such producers are 'generally regarded as safe' and designated as probiotics. Therefore, the one plausible opportunity to curb the ARPB (antibiotic resistant pathogenic bacteria) infections to humans is to deploy LAB strains, or to utilize bacteriocins produced by them, as protein antibiotics (Das and Goyal, 2014; Gupta et al.,, 2017). The probiotic potentiality assessment of different LAB strains takes an account of testing for physiological stressors tolerance, safety aspects and functionality (Halder et al.,, 2017), and before in vivo application, in order to get a benefit for a given health disorder or pathogenic infection to humans in vitro testing is mandatory in substantiating the preferred outcome (Gareau et al.,, 2010).

The gram-negative ARBP that pose severe global health threats include Escherichia coli, Pseudomonas aeruginosa, Acinetobacter baumannii, Klebsiella pneumoniae, Salmonella enterica serovar Typhi and Proteus vulgaris, while among the gram-positive bacteria, the MDR strains of Bacillus cereus, Enterococcus faecalis, Staphylococcus aureus and Listeria monocytogenes cause threats to the patients' safety. Antibiotics remain the basis of all kinds of therapies in modern healthcare systems, such as enabling the treatment life-threatening bacterial infection to humans (Van Boeckel et al.., 2014). However, the global emergence of multiple antibiotic resistant pathogenic bacteria necessitates for novel 
antimicrobials safe for human usage. The bacteriocin producing probiotic lactobacilli have been proved to be safe and suitable for biotherapy because of their capacity to display antibacterial activity against clinically relevant bacteria, or spoilage as well as food-borne pathogenic bacteria (Das and Goyal, 2014). Many authors isolated and identified, following conventional phenotypic characterization as well as $16 \mathrm{~S}$ rRNA gene sequencing, LAB strains from varied sources and characterized bacteriocins produced by them (Ge et al., 2016; Oliveira et al., 2017).Earlier, we have identified (by phenotypic characterization) a LAB strain, Lactobacillus fermentum LMEM22 procured from commercially available curd (West Bengal, India), checked the antibiogram and validated its antagonistic capacity against human pathogenic bacteria (Halder and Mandal, 2018). The current study was, thus, prompted to be undertaken in order to authenticate the probiotic attributes of the Lactobacillus fermentum LMEM22 strain through stressors tolerance, safety profiling, $16 \mathrm{~S}$ rRNA gene sequence analysis, and bacteriocin characterization.

\section{Materials And Methods}

\section{Bacterial strains and media}

The LAB strain, which was isolated from curd, identified as L. fermentum LMEM22 by conventional phenotypic characterization (Halder and Mandal, 2018), and maintained in MRS broth as well as in MRS agar stab in freezing, was utilized in the instant study. The indicator bacteria used include the randomly selected gram-negative (Escherichia coli, Pseudomonas aeruginosa, Acinetobacter baumannii, Klebsiella pneumoniae, Salmonella enterica serovar Typhi and Proteus vulgaris) and gram-positive (Bacillus cereus, Enterococcus faecalis, Staphylococcus aureus) clinical bacterial isolates from the laboratory stock cultures, and Listeria monocytogenes MTCC657 standard strain, which were maintained in cystine tryptone agar stabs, in refrigeration.

\section{Molecular identity of lactic acid bacterium}

The identity authentication of the bacteriocinogenic LAB strain was done by $16 \mathrm{~S}$ rRNA gene sequence and phylogenetic analyses. The $16 \mathrm{~S}$ rDNA $(\approx 1.5 \mathrm{~kb}$ fragment) was PCR amplified (from the genomic DNA extracted from the $L A B$ ) and thereafter sequenced using 16S rRNA specific primers (forward primer: 5'-AGHGTBTGHTCMTGNCTCAS-3' and reverse primer: 5'-TRCGGYTMCCTTGTWHCGACTH-3') from Chromous Biotech Pvt Ltd, India.

The sequenced data (partial 16S rRNA gene sequence: 672 bp) was aligned using ClastalW (Thompson et al.., 1994), and in the NCBI (National Center for Biotechnology Information) GenBank (http://blast.ncbi.nlm.nih.gov/Blast.cgi) the closest known relatives of the sequence obtained (from the test LAB strain) were determined through nucleotides homology search, with BLAST (Basic Local Alignment Search Tool), for nucleotide sequences (BLASTN).

The phylogenetic tree, based upon 16S rRNA gene sequences was constructed within the SeaView version-4 software (Gouy et al., 2010),following maximum likelihood method with PhyML GTR model 
(bootstrap with 1000 replicates). The partial 16S rRNA gene sequence of the test LAB strain has been deposited with the NCBI Genbank accession No. MH380182.

\section{Probiotic characterization}

The probiotic features of the test $L$. fermentum LMEM22 strain was substantiated through physiological stressors tolerance tests and safety profiling. The $L$. fermentum LMEM22 was subjected to probiotic characterization by performing bile salt and low-pH (acid) tolerance tests according to Liong and Shah (2005), and sodium chloride tolerance test following Chowdhury et al. (2012), with some alteration as cited before (Halder and Mandal, 2015; Halder et al.,, 2017).

In order to check the viability of the LAB at different incubation hours, the L. fermentum LMEM22 strain, with $\approx 5 \times 10^{5} \mathrm{CFU} / \mathrm{ml}\left(5.698 \log _{10} \mathrm{CFU} / \mathrm{ml}\right)$ inocula, was allowed to grow in presence of varied concentrations of sodium chloride (2, 4 and $6.5 \%$ ) and bile salts $(0.125,0.25$ and $0.5 \%)$, and under acidic environmental condition (at pH: 2, 3 and 4) in MRS broth, up to $24 \mathrm{~h}$, at $35^{\circ} \mathrm{C}$. Aliquots (each containing $100 \mu \mathrm{l})$, from the above mentioned cultures with different physiological stressors, were removed at $0,2,4$, 6 and $24 \mathrm{~h}$, mixed with MRS agar and pour plated, and following incubation at $35^{\circ} \mathrm{C}$ for $24 \mathrm{~h}, \mathrm{CFUs}$ were enumerated.

The safety properties of the $L A B, L$. fermentum LMEM22 strain, were validated by their hemolytic, gelatinase and DNase activity (Halder et al.,, 2017; Yadav et al.,, 2016).

\section{Isolation and quantification of bacteriocin}

Bacteriocin from the L. fermentum LMEM22 strain was extracted following Ismail et al. (2013), with modifications as explained below. Following subcultures of $L$. fermentum LMEM22 strain twice in MRS broth, $100 \mu \mathrm{l}$ was inoculated into $25 \mathrm{ml}$ of MRS broth, and after incubation at $37^{\circ} \mathrm{C}$ for $48 \mathrm{~h}$, cell free supernatant (CFS) was prepared by centrifugation (at $10,000 \mathrm{rpm}$, for 10 minutes at $4^{\circ} \mathrm{C}$ ) and syringe filtration. The CFS was treated with $60 \%$ ammonium sulfate at $4^{\circ} \mathrm{C}$ for $24 \mathrm{~h}$ to get precipitated the bacteriocin, which by centrifugation (at $12,000 \mathrm{rpm}$ for 15 minutes at $4^{\circ} \mathrm{C}$ ), was extracted. The isolated bacteriocin was processed by washing with sterilized double distilled water and centrifuging (at 10,000 $\mathrm{rpm}$ for 10 minutes at $4^{\circ} \mathrm{C}$ ) for thrice, in order to remove the impurities in bacteriocin. At the final stage, pure bacteriocin pellet was mixed with phosphate buffer solution ( $1 \mathrm{ml}, \mathrm{pH} \mathrm{7.2)}$, with $0.6 \%$ SDS, and stored at $4^{\circ} \mathrm{C}$ for further usage.

The bacteriocin yield was quantified spectrophotometrically, following Lowry et al. (1951), using bovine serum albumin as the standard.

\section{SDS-PAGE analysis of bacteriocin}


The molecular weight of bacteriocin isolated from L. fermentum LMEM22 strain was approximated by glycine-SDS-PAGE (glycine-sodium dodecyl sulfate-polyacrylamide gel electrophoresis) analysis (Laemmli, 1970), using a vertical slab gel apparatus (Tarsons, India) with $7.5 \%$ stacking and $12.5 \%$ separating gels, and high range protein molecular markers (Hi-Media, India). Following electrophoresis for $4 \mathrm{~h}$ at $130 \mathrm{~V}$, the gel was subjected to Coomassie brilliant blue (Hi-Media, India) staining (for $30 \mathrm{~min}$ ) and thereafter de-staining in 20\% (v/v) methanol / 7.5\% (v/v) glacial acetic acid until the bands were clearly visible. The molecular weight of $L$. fermentum LMEM22 bacteriocin was calculated from the relative mobility of the molecular weight markers in the gel.

\section{Antibacterial activity of bacteriocin}

The antibacterial activity of $L$. fermentum LMEM22 bacteriocin was determined by agar-well diffusion following Tagg and McGiven (Tagg and McGiven, 1971), using 66.67- $\mu \mathrm{g}$ bacteriocin per well $(6 \mathrm{~mm}$ diameter), prepared on nutrient agar plate, which was swabbed with the overnight grown culture of indicator bacterial strains in nutrient broth, and the ZDIs were measured (in nearest whole in millimeter), in order to interpret the effectiveness of bacteriocin, following the criteria mentioned earlier ${ }^{6}$, as less active, moderately active, or highly active through ZDIs $\leq 10 \mathrm{~mm}, 11-14 \mathrm{~mm}$, and $\geq 15 \mathrm{~mm}$, respectively.

For the determination of MICs of $L$. fermentum LMEM22 bacteriocin, against the indicator bacteria, broth dilution method was used as mentioned elsewhere (Wiegand et al.,, 2008), utilizing random bacteriocin concentrations of $30-200 \mu \mathrm{g} / \mathrm{ml}$, in nutrient broth. Inoculation of indicator bacteria, from overnight grown nutrient broth cultures, was done; all incubations were at $35^{\circ} \mathrm{C}$ for $24 \mathrm{~h}$. The lowest bacteriocin concentration, which was required to inhibit the visible growth of test pathogenic bacteria, was defined as the MIC.

\section{Enzymatic sensitivity of bacteriocin}

The enzymatic effect on the bacteriocin isolated from L. fermentum LMEM22, against protease K, trypsin, and a-amylase, was evaluated following the protocol of $\mathrm{Ge}$ et al (Ge et al., 2016). The test bacteriocin was mixed with each of the enzymes $(10 \mathrm{mg} / \mathrm{ml})$ and incubated at $37^{\circ} \mathrm{C}$ for $24 \mathrm{~h}$, and afterward the mixture was boiled at $80^{\circ} \mathrm{C}$ for 5 min for enzyme inactivation. The $L$. fermentum LMEM22 bacteriocin without any enzymatic treatment was used as the control, in determining the residual bacteriocin activity (RBA), following agar-well diffusion against gram-positive (Staphylococcus aureus and Listeria monocytogenes) as well as gram-negative (Acinetobacter baumannii and Escherichia coli) human pathogenic bacteria. The RBA was computed based on the ratio of bacterial growth inhibition (in terms of ZDI) with treatment and with the control (Ge et al., 2016).

\section{Results}


Based upon the 16S rRNA gene sequence and phylogeny analysis, the LAB strain of curd origin, LMEM22, has been found to be closest to Lactobacillus fermentum hani.A ton 2 KM214424, and was identified as Lactobacillus fermentum LMEM22 (Fig. 1), the NCBI GenBank accession No. for which is MH380182. The antibacterial bacteriocin producing $\mathrm{Y}$-haemolytic L. fermentum strain LMEM22 (Fig.1), for which gelatinase and DNase activities were negative, had tolerance to high sodium chloride concentration ( $2 \%$ $-6.5 \%)$ and temperature $\left(15^{\circ} \mathrm{C}-42^{\circ} \mathrm{C}\right)$ range, acidic milieu $(\mathrm{pH}: 2.0-4.0)$ and bile salts $(0.125-0.5 \%)$, as represented in Table 1.

A single band of $13.1 \mathrm{kDa}$ bacteriocin, based on the glycine-SDS-PAGE analysis, was isolated from the Lactobacillus fermentum strain LMEM22, which possessed antibacterial capacity (Fig. 2); the $13.1 \mathrm{kDa}$ LMEM22 bacteriocin yield has been recorded as $1.656 \mathrm{mg} / \mathrm{ml}$.

The LMEM22 bacteriocin had antibacterial activity against gram-negative (Acinetobacter baumannii, Escherichia coli, Klebsiella pneumoniae, Pseudomonas aeruginosa, Salmonella enterica serovar Typhi and Proteus vulgaris) and gram-positive (Bacillus cereus, Enterococcus faecalis, Staphylococcus aureus and Listeria monocytogenes) human pathogenic bacteria displaying respective ZDI (zone diameter of inhibition) values of 19-23 mm and 17-24 mm (Fig. 3), by agar-well diffusion. The minimum inhibitory concentration (MIC) values, as have been determined by agar dilution, ranged 50-199 $\mu \mathrm{g} / \mathrm{ml}$, for gramnegative bacteria, and $41-132 \mu \mathrm{g} / \mathrm{ml}$, for gram-positive bacteria (Fig. 4).

The effect of enzymes on the L. fermentum LMEM22 bacteriocin, in terms of the antibacterial activity, has been represented in Table 2. When treated with enzymes, proteinase $K$ and trypsin, the bacterial growth inhibition capacity (in terms of ZDI) of L. fermentum LMEM22 bacteriocin, against gram-positive: Staphylococcus aureus and Listeria monocytogenes as well as gram-negative: Acinetobacter baumannii and Escherichia coli, test bacteria was reduced by $3-5 \mathrm{~mm}$ (both for gram-positive and gram-negative bacteria) compared to the untreated bacteriocin activity, while mostly the bacteriocin activity was unaffected by a-amylase.

\section{Discussion}

This study authenticates the probiotic competency of a native $L$. fermentum LMEM22 strain from curd by means of safety profiling and functionality (stability against selective physiological stress and antibacterial efficacy) testing, and the identity confirmation, as well through 16S rRNA gene sequencing. The sequence determination of 16S rRNA genes of the genus Lactobacillus provides precise information on their phylogeny and identification (Vandamme et al.,, 1996). The 16S rRNA gene analysis, using the universal primers (forward: 5'-AGAGTTTGATCCTGGCTCAG-3' and reverse: 5'-

TACGGCTACCTTGTTACGACTT-3'), of two heterofermentative lactobacilli isolates showed $99 \%$ similarity to $L$. fermentum, while the two homofermentative isolates had similarity with $L$. plantarum, as has been demonstrated by Patil et al. (2010). A set of forward primer: 5'-AGHGTBTGHTCMTGNCTCAS-3' and reverse primer: 5'-TRCGGYTMCCTTGTWHCGACTH-3' has been utilized in the PCR amplification of 16S rRNA in order to recognize the identity of LAB strains isolated from a variety of sources (Roy and Rai, 
2017). A non-spore forming gram-positive, but catalase and oxidase negative rod shaped LAB strain, LMEM22, which was conventionally identified as L. fermentum LMEM22 (Das and Goyal, 2014), has been subjected to molecular based identification, in this study, by 16S rRNA gene sequencing and phylogeny analysis. The identity of the test strain, being closest to Lactobacillus fermentum hani.A ton 2 KM214424, was confirmed as L. fermentum LMEM22 (the NCBI GenBank accession number for which is MH380182).

Based upon the physiological stressor tolerance (bile salts, low-pH and sodium chloride) and safety profiles ( $\gamma$-haemolysis and inept to gelatinase and DNase production), the L. fermentum LMEM22 has been substantiated as a potential probiotic strain, following the criteria mentioned earlier (Gareau et al.,, 2010; Halder et al.,, 2017). In addition, a vital probiotic feature that signifies the safe consumption of indigenous LAB strain is the antibiotic sensitivity (to avoid the risk of resistance transferability) and the intrinsic resistance (chromosomally conferred due to point mutation) as well (Georgieva et al., 2015; Jose et al.,, 2015), for co-administration of probiotic with antibiotic (Mombelli and Gismondo, 2000). The isolated L. fermentum LMEM22 strain had been found to be safe, on the basis of non-transferable nature of antibiotic resistance (Ammor et al., 2008; Imperial and Ibana, 2016), and thus, the current study validated the single-strain based (L. fermentum LMEM22) probiotic benefit for people in our part of the globe (Malda, West Bengal state, India).

In order to muddle through the escalating incidence of antimicrobial resistance (AMR) among human pathogenic bacteria a class of protein antibiotics, the bacteriocins, produced especially by probiotic LAB strains, has been paid an immense attention, because of their stupendous capacity to antagonize the human pathogenic bacteria, including the WHO priority pathogens (Mycobacterium tuberculosis, Clostridium difficile and Staphylococcus aureus) too (Cotter et al., 2015; WHO, 2017). The bacteriocin of $9.5 \mathrm{kDa}$ from cow milk derived LAB strain, Lactobacillus plantarum, had antibacterial activity, having ZDI (zone diameter of inhibition) values 11-21 mm, against Escherichia coli, Enterococcus faecalis, Listeria monocytogenes and Staphylococcus aureus (Sankar et al., 2012). The antibacterial activity of LAB bacteriocin has been reported earlier. It has been shown that the 1,77 kDa bacteriocin MN047A, isolated from Lactobacillus crustorum MN047 had broad spectrum antibacterial activity against gram-positive bacteria: Staphylococcus aureus isolates (ZDI: 20-23 mm), Enterococcus faecalis (ZDI: $22 \mathrm{~mm}$ ) and Listeria monocytogenes (ZDI: $22 \mathrm{~mm}$ ), and gram-negative bacteria: Escherichia coli (ZDI: $21 \mathrm{~mm})$, Salmonella spp. (ZDI: 20-21 mm), (ZDI: $21 \mathrm{~mm})$, Enterobacter sakazakii isolates (ZDI: 19-21 mm), and the bacteriocin had MICs of 165 and $305 \mu \mathrm{g} / \mathrm{ml}$ against S. aureus ATCC 29213 and E. coli ATCC 25922, respectively (Yi et al.,, 2016). The subtilosin A bacteriocin has been reported to display broad range of MICs, from $1.25 \mu \mathrm{g} / \mathrm{ml}$, for Shigella sonnei ATCC 25931, Enterobacter aerogenes ATCC 13408, Klebsiella pneumoniae UMN5 and Streptococcus pyogenes ATCC 19615 strains, to $>200 \mu \mathrm{g} / \mathrm{ml}$, for Bacillus cereus ATCC 10876, Staphylococcus epidermidis ATCC 12228, Bacillus subtilis ATCC 6633, Klebsiella pneumoniae ATCC 4352, Proteus mirabilis ATCC 25933, Salmonella enterica Typhi ATCC 12048 strains (Shelburne et al.,, 2007). As per the report of Sharma et al. (2018), a bacteriocin of $\approx 6.5 \mathrm{kDa}$ from Bacillus subtilis GAS101, has been found to be the potential inhibitor of Staphylococcus epidermidis and Escherichia coli. The bacteriocin of $2.7 \mathrm{kDa}$ isolated from Weissella confusa A3 strain had antibacterial 
activity against gram-positive (Bacillus cereus ATCC14579 and Micrococcus luteus ATCC10240) and gram-negative (Escherichia coli UT181 and Pseudomonas aeruginosa PA7) bacteria, displaying MICs of $9.25 \mu \mathrm{g} / \mathrm{ml}$ and $18.5 \mu \mathrm{g} / \mathrm{ml}$, respectively, while the ZDIs ranged $7.98-11.83 \mathrm{~mm}$ (Goh and Philip, 2015). Elayaraja et al.(2014) demonstrated the antibacterial activity of $21 \mathrm{kDa}$ Lactobacillus murinus AU06 bacteriocin against gram-positive (S. aureus, Micrococcus sp., Bacillus licheniformis, Enterococcus faecalis, Listeria monocytogenes) and gram-negative (Escherichia coli, Pseudomonas aeruginosa) bacteria, with ZDIs $10-28$ and $18-22 \mathrm{~mm}$, respectively. The bacteriocin, paracin 1.7 of $\approx 10 \mathrm{kDa}$, produced by L. paracaseiHD1-7 strain, had a wide spectrum of growth-inhibitory effect on Staphylococcus, Micrococcus and Bacillus (gram-positive bacteria) as well as Proteus, Escherichia, Enterobacter, Pseudomonas and Salmonella (gram-negative bacteria), as has been reported by Ge et al. (2009). The $\approx 13 \mathrm{kDa}$ L. fermentum LMEM22 bacteriocin, in the current study, had broad antibacterial capacity (against bacteria of clinical relevance) displaying ZDIs of 17-23 mm and MICs of 41-199 $\mu \mathrm{g} / \mathrm{ml}$.

The protein/peptide nature of LAB bacteriocin has been specified previously through enzyme (proteolytic) sensitivity testing, wherein the disbanding of antibacterial capacity of such protein antimicrobials by enzymes (proteinase $\mathrm{K}$, chymotrypsin and trypsin) validated their (bacteriocins) proteinaceous nature (Xiraphi et al.,, 2008; Ge et al., 2016). The bacteriocin of L. fermentum sl36 strain isolated from goat milk, which inhibited the growth of food-borne bacteria (Enterococcus faecalis, Listeria monocytogenes, Listeria innocua, Staphylococcus aureus, Pseudomonas aeruginosa and Escherichia coli), lost the antibacterial activity, against gram-positive strains, after treatment with trypsin (Mitjans et al.,, 2018). The antimicrobial bacteriocin Lac-B23, of $\approx 6.73 \mathrm{kDa}$ from L. plantarum J23 strain, demonstrated complete loss of anti-Listeria monocytogenes activity on being treated with proteinase $K$, trypsin, and proteinase $E$, indicating the complete disruption of bacteriocin Lac-B23, by proteolytic enzymes, due to its proteinaceous nature (Zhang et al.,, 2018).As has been reported by Todorov et al. (2013), the Lactobacillus sakei strains ST22Ch, ST153Ch and ST154Ch (from fermented meat products), containing bacteriocin of $3 \mathrm{kDa}, 10 \mathrm{kDa}$ and $3 \mathrm{kDa}$, respectively (in tricine/SDS-PAGE), which inhibited the growth of gram-positive (Enterococcus spp., Staphylococcus spp., Listeria spp. and Streptococcus spp.) and gramnegative (Escherichia coli, Pseudomonas spp. and Klebsiella spp.) bacteria, demonstrating a decrease of antibacterial action with proteinase $\mathrm{K}$ and pronase treatment of the bacteriocin, but not due to a-amylase treatment. The bacteriocins of $L$. plantarum, $L$. pentosus and $L$. paracasei displaying growth inhibitory effect against Salmonella and $S$. aureus with ZDIs $13.08 \pm 0.15-15.22 \pm 0.13 \mathrm{~mm}$, lost their antimicrobial action after treatment with proteolytic enzymes (proteinase K, pepsin, and papain), as has been reported by Ren et al. (2018). In the current study, on enzymatic treatment with proteinase $K$ and trypsin, the $L$. fermentum LMEM22 bacteriocin activity has been found to be decreased when tested against grampositive (Staphylococcus aureus and Listeria monocytogenes) as well as gram-negative (Acinetobacter baumannii and Escherichia coli) indicator bacteria, and the bacteriocin was found insensitive against aamylase activity, authenticating its proteinaceous nature, which was in accordance to the report of the earlier authors (Ge et al., 2016; Fahim et al.,, 2017). 


\section{Conclusion}

The isolated $L$. fermentum LMEM22 bacteriocin $(13.1 \mathrm{kDa})$ of proteinaceous nature had broad spectrum antibacterial activity against an array of gram-positive (ZDIs: $17-24 \mathrm{~mm}$; MICs: $41-132 \mu \mathrm{g} / \mathrm{mL}$ ) and gram-negative (ZDIs: 19-23 mm; MICs: 50-199 $\mu \mathrm{g} / \mathrm{ml}$ ) bacteria of clinical importance, and the bacteriocinogenic LAB L. fermentum LMEM22 strain accomplished the probiotic attributes along with the indispensable safety profiles so as to be safe for human consumption, at least in our developing part of the globe. However, in order to resolve whether the beneficial effect is shaped enough by the live form of L. fermentum LMEM22 strain of curd origin and/or the bacteriocin produced by this LAB further studies (animal model/clinical trials) are warranted for global usage.

\section{Declarations}

Conflicts of interest: Authors declared that they have no conflicts of interests.

Funding source: There was no fund for this work.

Author's contributions: Debashis Halder: performed experimental work; Manisha Mandal: designed the study, standardized the protocols, co-wrote; Nishith Kumar Pal: designed the study, identified the target pathogenic bacteria; Shyamapada Mandal: designed the study, standardized the protocols, wrote and discussed the paper.

\section{References}

1. Ammor MS, Florez AB, van Hoek AH, de los Reyes-Gavilan CG, Aarts HJ, Margolles A and Mayo B, Molecular characterization of intrinsic and acquired antibiotic resistance in lactic acid bacteria and bifidobacteria. J Mol Microbiol Biotechnol, 14 (2008) 6. DOI: 1159/000106077

2. Bosak J, Micenkova L, Hrala M, Pomorska K, Bosakova MK, Krejci P, Gopfert E \& Smajs D, Colicin FY inhibits pathogenic Yersinia enterocolitica in mice. Sci Rep 8 (2018) 12242. https://doi.org/10.1038/s41598-018-30729-7

3. Chowdhury A, Hossain MN, Mostazir NJ, FakruddinMd, Billah M and Ahmed MM, Screening of Lactobacillus sp. from buffalo yoghurt for probiotic and antibacterial activity. J Bacteriol Parasitol, 3 (2012) 1. DOI: 10.4172/2155-9597.1000156

4. Cotter PD, Ross RP \& Hill C. Bacteriocins - a viable alternative to antibiotics? Nat Rev Microbiol, 11 (2013) doi: 10.1038/nrmicro2937

5. Das D \& Goyal A, Characterization of a noncytotoxic bacteriocin from probiotic Lactobacillus plantarumDM5 with potential as a food preservative. Food Funct, 5 (2014) 2453.

DOI: 1039/C4F000481G

6. Dobson A, Cotter PD, Ross RP \& Hill C, Bacteriocin production: a probiotic trait? Appl Environ Microbiol, 78 (2012) 1. DOI:1128/AEM.05576-11 
7. Elayaraja S, Annamalai N, Mayavu P \& Balasubramanian T, Production, purification and characterization of bacteriocin from Lactobacillus murinus AU06 and its broad antibacterial spectrum. Asian Pac J Trop Biomed, 4 (2014) S305. doi: 10.12980/APJTB.4.2014C537

8. Fahim HA, Waleed MA, Rouby E, El-Gendy AO \& Khairalla AS, Naguib IA and Farghali AA, Enhancement of the productivity of the potent bacteriocin avicin A and improvement of its stability using nanotechnology approaches. Sci Rep, 7 (2017) https://doi.org/10.1038/s41598-017-10157-9

9. Gareau MG, Sherman PM \& Walker WA, Probiotics and the gut microbiota in intestinal health and disease. Nat Rev Gast Hepatol, 7 (2010) 503. doi: 10.1038/nrgastro.2010.117

10. Ge J, Ping W, Song G, Du C, Ling H, Sun X and Gao Y, Paracin 1.7, a bacteriocin produced by Lactobacillus paracasei 7 isolated from Chinese cabbage sauerkraut, a traditional Chinese fermented vegetable food. Acta microbiologica Sinica, 49 (2009) 609.

11. Ge J, Sun $Y$, Xin X, Wang $Y$ \& Ping W, Purification and partial characterization of a novel bacteriocin synthesized by Lactobacillus paracasei HD1-7 isolated from Chinese sauerkraut juice. Sci Rep, 6 (2016) 19366. doi: 10.1038/srep19366.

12. Georgieva R, Yocheva L, Tserovska L, Zhelezova G, Stefanova N \& Atanasova A, Antimicrobial activity and antibiotic susceptibility of Lactobacillus and Bifidobacterium intended for use as starter and probiotic cultures. Biotechnol Biotechnol Equip, 29 (2015) 84. Doi:

10.1080/13102818.2014.987450

13. Goh HF \& Philip K, Purification and characterization of bacteriocin produced by Weissella confusa A3 of dairy origin. PLOS ONE, 10 (2015) 1. https://doi.org/10.1371/journal.pone.0140434

14. Gouy M, Guindon S \& Gascuel O, SeaView Version 4: A multiplatform graphical user interface for sequence alignment and phylogenetic tree building. Mol Bio Evol, 27 (2010) 221. doi:

10.1093/molbev/msp259

15. Gupta V, Nag D \& Garg P, Recurrent urinary tract infections in women: How promising is the use of probiotics? Ind J Med Microbiol, 35 (2017) 347. doi: 10.4103/ijmm.IJMM_16_292

16. Halder D \& Mandal S, Curd lactobacilli with probiotic potentiality. Trans Biomed, 6 (2015) 1. DOI: $10.21767 / 2172-0479.100008$

17. Halder D, Mandal M, Chatterjee SS, Pal NK \& Mandal S, Indigenous probiotic Lactobacillus isolates presenting antibiotic like activity against human pathogenic bacteria. Biomedicines, 5 (2017) doi: 10.3390/biomedicines5020031

18. Halder D \& Mandal S, Insights into the antagonism of Lactobacillus fermentum curd isolate against gram-positive and gram-negative pathogenic bacteria. Biosci Biotech Res Comm, 11 (2018) 461. DOI: $10.21786 / \mathrm{bbrc} / 11.3 / 15$

19. Imperial ICVJ \& Ibana JA, Addressing the antibiotic resistance problem with probiotics: reducing the risk of its double-edged sword effect. Front Microbiol, 7 (2016) 1. doi: 10.3389/fmicb.2016.01983

20. Ismail INA, Noor HM, Muhamad HS, Radzi SM, Kader AJA, Rehan MM, Mohamad R, Protein produced by Lactobacillus plantarum ATCC 8014 during Stress. World J Sci Technol Res, 1 (2013) 174. 
21. Jose NM, Bunt CR \& Hussain MA, Implications of antibiotic resistance in probiotics. Food Rev Int, 31 (2015) 52. Doi: 10.1080/87559129.2014.961075

22. Laemmli UK, Cleavage of structural proteins during the assembly of the head of bacteriophage T4. Nature, 277 (1970) 680. DOI: 1038/227680a0

23. Liong MT \& Shah NP, Acid and bile tolerance and cholesterol removal ability of lactobacilli strain. $J$ Dairy Sci, 88 (2005) 55. DOI: 3168/jds.S0022-0302(05)72662-X

24. Lowry OH, Rosebrough NJ, Farr Al \& Randall RJ, Protein measurement with the folin phenol reagent. J Biol Chem, 193 (1951)

25. Mitjans NM, Coria MJ, Alfonso JO \& Stagnitta PV, Antimicrobial effect of bacteriocin from Lactobacillus fermentum isolated from goat milk on perishable foods. San Luis. Argentina. Int $J$ Engineering Res Sci, 4 (2018) 35.

26. Mombelli B \& Gismondo MR. The use of probiotics in medical practice. Int J Antimicrob Agent, 16 (2000) DOI: 10.1016/s0924-8579(00)00322-8

27. Oliveira LC, Saraiva TDL, Silva WM, Pereira UP, Campos BC, Benevides LJ, Rocha FS, Figueiredo HCP, Azevedo V \& Soares SC, Analyses of the probiotic property and stress resistance-related genes of Lactococcus lactislactis NCDO 2118 through comparative genomics and in vitro assays. PLoS ONE, 12 (2017) 1. doi: 10.1371/journal.pone.0175116

28. Patil MM, Pal A, Anand T \& Ramana KV. Isolation and characterization of lactic acid bacteria from curd and cucumber. Indian J Biotechnol, 9 (2010) 166.

29. Ren D, Zhu J, Gong S, Liu H \& Yu H. Antimicrobial characteristics of lactic acid bacteria isolated from homemade fermented foods. BioMed Res Int, (2018) 1. https://doi.org/10.1155/2018/5416725

30. Roy A \& Rai C, Isolation and characterization of lactic acid bacteria with probiotic potential from pickles. Biosci Discover, 8 (2017) 866.

31. Sankar NR, Priyanka VD, Reddy PS, Rajanikanth P, Kumar KK \& Indira M, Purification and characterization of bacteriocin produced by Lactobacillus plantarum isolated from cow milk. Int $\mathrm{J}$ Microbiol Res, 3 (2012) 133. DOI: 10.5829/idosi.ijmr.2012.3.2.62182

32. Sharma G, Dang S, Gupta S \& Gabrani R, Antibacterial activity, cytotoxicity, and the mechanism of action of bacteriocin from Bacillus subtilis Med Princ Pract 27 (2018) 186. DOI: 10.1159/000487306

33. Shelburne CE, An FY, Dholpe V, Ramamoorthy A, Lopatin DE \& Lantz MS, The spectrum of antimicrobial activity of the bacteriocin subtilosin A. J Antimicrob Chemother, 59 (2007) 297. DOI: 1093/jac/dkl495

34. Tagg JR \& McGiven AR, Assay system for bacteriocins. App/ Microbiol, 21 (1971) 943.

35. Thompson JD, Higgins DG \& Gibson TJ, ClustalW: improving the sensitivity of progressive multiple sequence alignment through sequence weighting, position-specific gap penalties and weight matrix choice. Nucleic Acids Res, 22 (1994) 4673. doi: 1093/nar/22.22.4673

36. Todorov SD, Vaz-Velho M, Franco BDGM \& Holzapfel WH, Partial characterization of bacteriocins produced by three strains of Lactobacillus sakei, isolated from salpicao, a fermented meat product 
from North-West of Portugal. Food Control, 30 (2013) 111. Doi: 1016/j.foodcont.2012.07.022

37. Usui M, Hiki M, Murakami K, Ozawa M, Nagai H \& Asai T, Evaluation of transferability of r-plasmid in bacteriocin-producing donors to bacteriocin-resistant recipients. Jpn J Infect Dis, 65 (2012) 252. DOI: 10.7883/yoken.65.252

38. Van Boeckel TP, Gandra S, Ashok A, Caudron Q, Grenfell BT, Levin SA \& Laxminarayan R, Global antibiotic consumption 2000 to 2010: an analysis of national pharmaceutical sales data. Lancet Infect Dis, 14 (2014) 742. 1016/S1473-3099(14)70780-7

39. Vandamme P, Pot B, Gillis M, DeVos P, Kerters K \& Swing J, Polyphasic taxonomy, a consensus approach to bacterial systematics. Microbiol Rev, 60 (1996)

40. WHO, Antibacterial agents in clinical development. WHO, 2017.

41. Wiegand I, Hilpert K \& Hancock REW, Agar and broth dilution methods to determine the minimal inhibitory concentration (MIC) of antimicrobial substances. Nat Protocol, 3 (2008) 163. doi: 10.1038/nprot.2007.521.

42. Xiraphi M, Georgalaki M, Rantsiou K, Cocolin L, Tsakalidou E and Drosinos EH, Purification and characterization of a bacteriocin produced by Leuconostoc mesenteroides Meat Sci, 80 (2008) 194. DOI: 10.1016/j.meatsci.2007.11.020

43. Yadav R, Puniya AK \& Shukla P, Probiotic properties of Lactobacillus plantarumRYPR1 from an indigenous fermented beverage raabadi. Front Microbiol, 7 (2016) DOI: 10.3389/fmicb.2016.01683

44. Yi L, Dang Y, Wu J, Zhang L, Liu X, Liu B, Zhou Y and Lu X, Purification and characterization of a novel bacteriocin produced by Lactobacillus crustorum MN047 isolated from koumiss from Xinjiang, China. J Dairy Sci, 99 (2016) 7002. doi: 10.3168/jds.2016-11166

45. Zhang J, Yang Y, Yang H, Bu Y, Yi H, Zhang L, Han X and Ai L, Purification and partial characterization of bacteriocin Lac-B23, a novel bacteriocin production by Lactobacillus plantarum J23, isolated from Chinese traditional fermented milk. Front Microbiol, 9 (2018) 2165. doi: 3389/fmicb.2018.02165

\section{Tables}

Table 1 Stressors tolerance of L. fermentum LMEM22 stain 


\begin{tabular}{|lllllll|}
\hline $\begin{array}{l}\text { Physiological } \\
\text { stressors }\end{array}$ & $\begin{array}{l}\text { Level of stressors } \\
\text { exposed }\end{array}$ & \multicolumn{5}{l}{$\begin{array}{l}\log _{10} \mathrm{CFU} / \mathrm{mL} \text { at different hours of } \\
\text { incubation }\end{array}$} \\
\cline { 2 - 7 } & & 0 & 2 & 4 & 6 & 24 \\
\hline $\mathrm{pH}$ & 2.0 & 5.699 & 7.736 & 7.619 & 7.761 & 7.968 \\
& 3.0 & 5.699 & 7.806 & 7.829 & 7.952 & 8.085 \\
\hline Bile salts (\%) & 4.0 & 5.699 & 7.848 & 7.867 & 7.92 & 8.255 \\
& 0.125 & 5.699 & 8.049 & 8.118 & 8.204 & 8.38 \\
\hline $\mathrm{NaCl}(\%)$ & 0.25 & 5.699 & 7.928 & 7.968 & 7.997 & 8.304 \\
& 0.5 & 5.699 & 7.903 & 7.92 & 7.982 & 8.267 \\
\hline & 2 & 5.699 & 8.043 & 8.061 & 8.091 & 8.476 \\
\hline & 4 & 5.699 & 8.024 & 8.043 & 8.085 & 8.338 \\
\hline
\end{tabular}

CFU: colony forming unit

Table 2 Effect of enzymes on the antibacterial activity L. fermentum LMEM22 bacteriocin

\begin{tabular}{|lllll|}
\hline Treatment against & E. coli & \multicolumn{3}{l|}{ A. baumannii } \\
\cline { 2 - 5 } gram-positive bacteria & ZDI (mm) & \% activity & ZDI (mm) & \% activity \\
\hline Proteinase K & 16 & 76.19 & 20 & 86.96 \\
\hline Trypsin & 16 & 76.19 & 20 & 86.96 \\
\hline a-amylase & 18 & 85.71 & 22 & 95.65 \\
\hline Control & 21 & 100 & 23 & 100 \\
\hline Treatment against & S. aureus & & L. monocytogenes \\
\cline { 2 - 4 } gram-positive bacteria & ZDI (mm) & $\%$ activity & ZDI (mm) & $\%$ activity \\
\hline Proteinase K & 20 & 83.33 & 12 & 70.59 \\
\hline Trypsin & 21 & 87.5 & 13 & 76.47 \\
\hline a-amylase & 23 & 95.83 & 16 & 94.18 \\
\hline Control & 24 & 100 & 17 & 100 \\
\hline & & & & \\
\hline
\end{tabular}


ZDI: zone diameter of inhibition

\section{Figures}

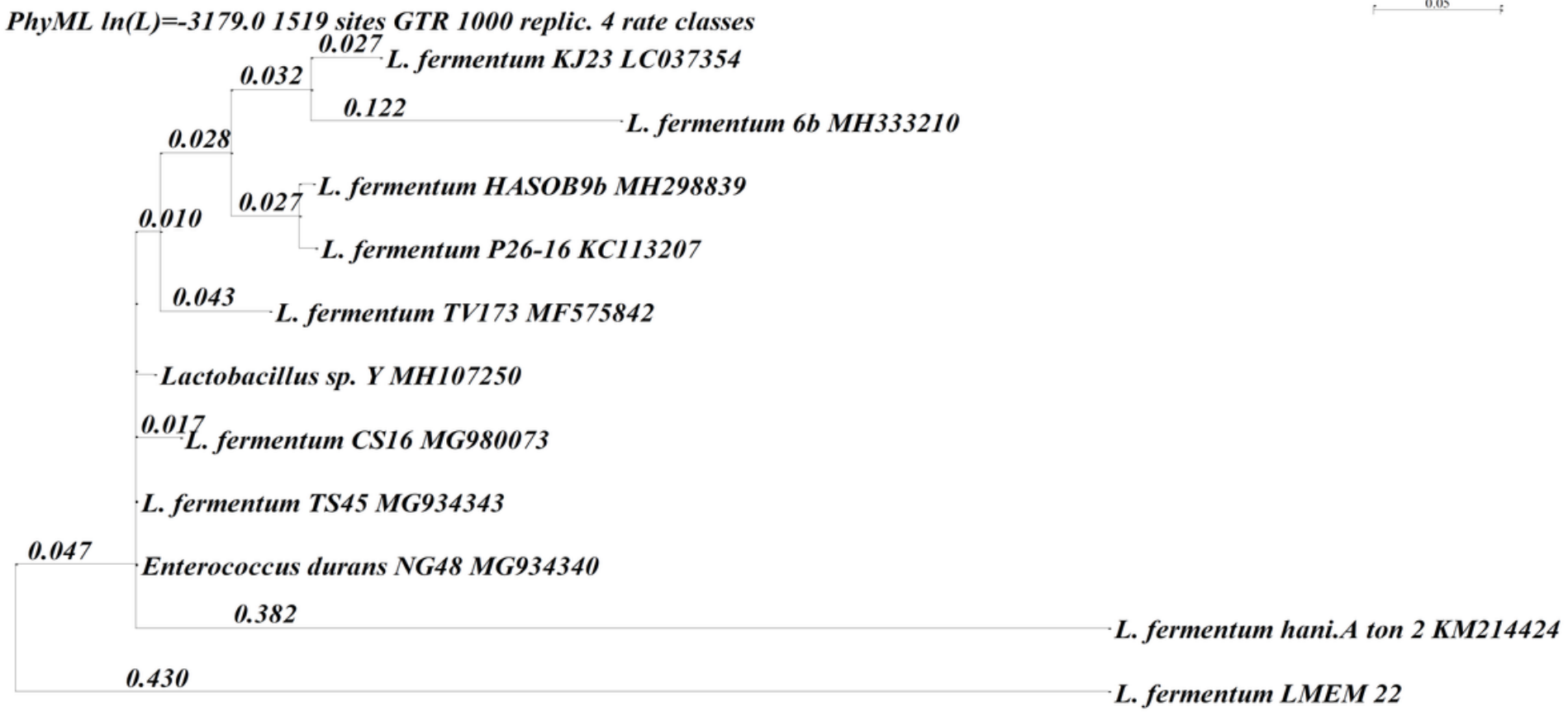

\section{Figure 1}

The 16S rRNA gene sequence based phylogenetic tree for Lactobacillus fermentum LMEM22 strain compared with the sequences of closely related reference bacterial strains retrieved from NCBI GenBank database. 


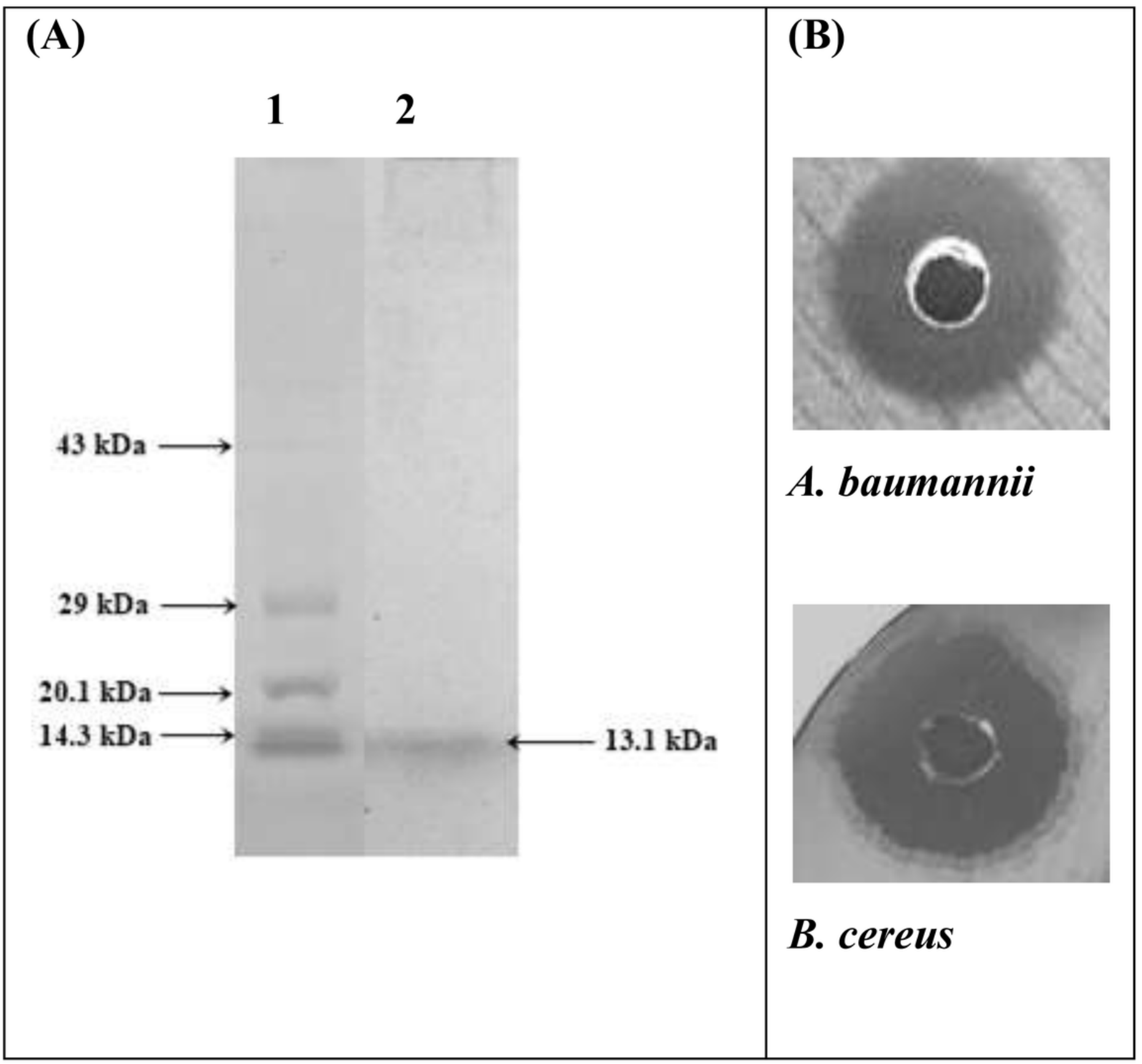

Figure 2

Molecular mass approximation and antibacterial activity of bacteriocin isolated from L. fermentum LMEM22. (A) SDS-PAGE image: lane 1: protein molecular weight standards; 2: L. fermentum LMEM22 bacteriocin, (B) L. fermentum LMEM22 bacteriocin antibacterial activity against $A$. baumannii and B. cereus by agar-well diffusion. 


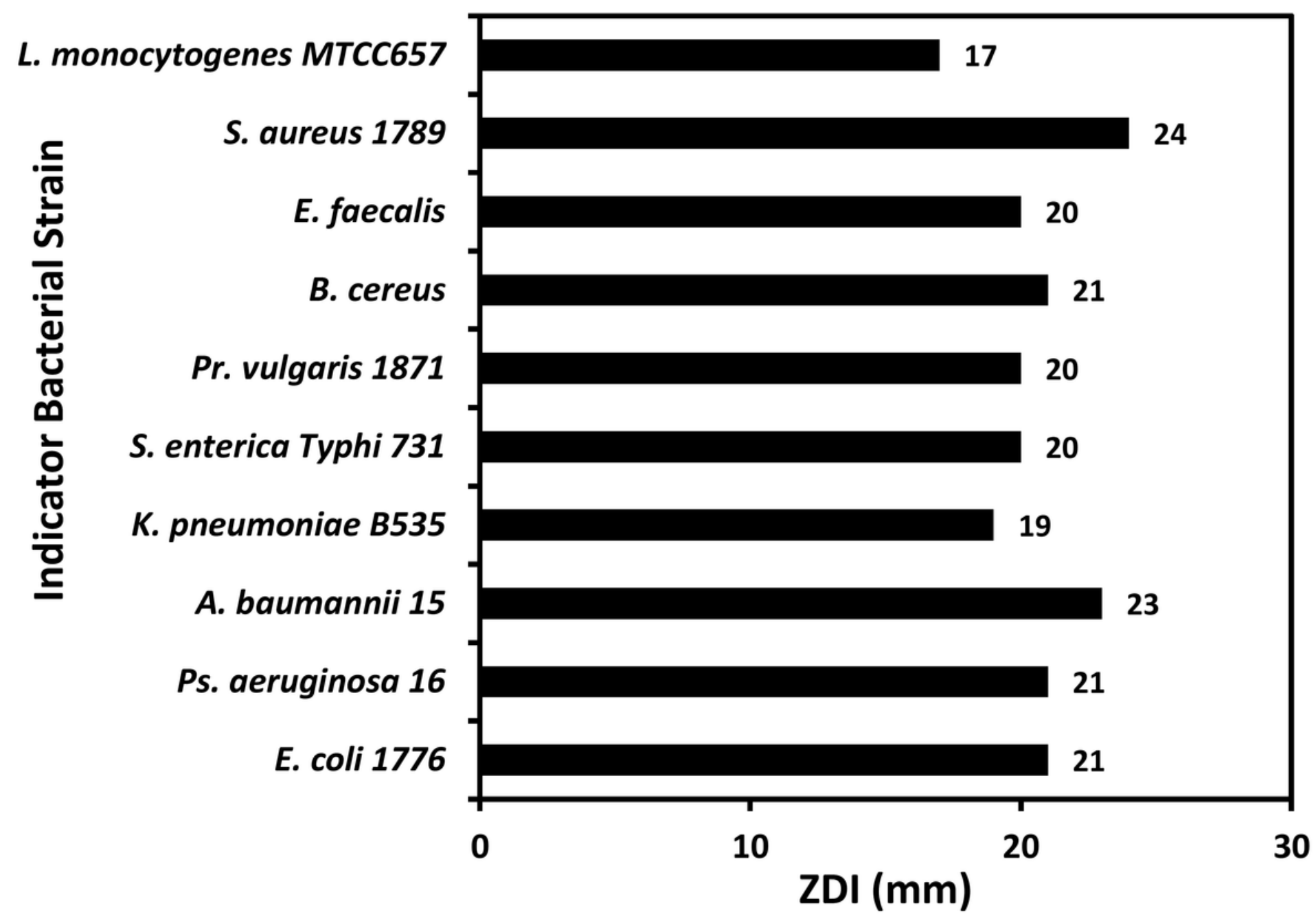

Figure 3

Agar-well diffusion test results of L. fermentum LMEM22 bacteriocin action against indicator bacterial strains; ZDI: zone diameter of inhibition. 


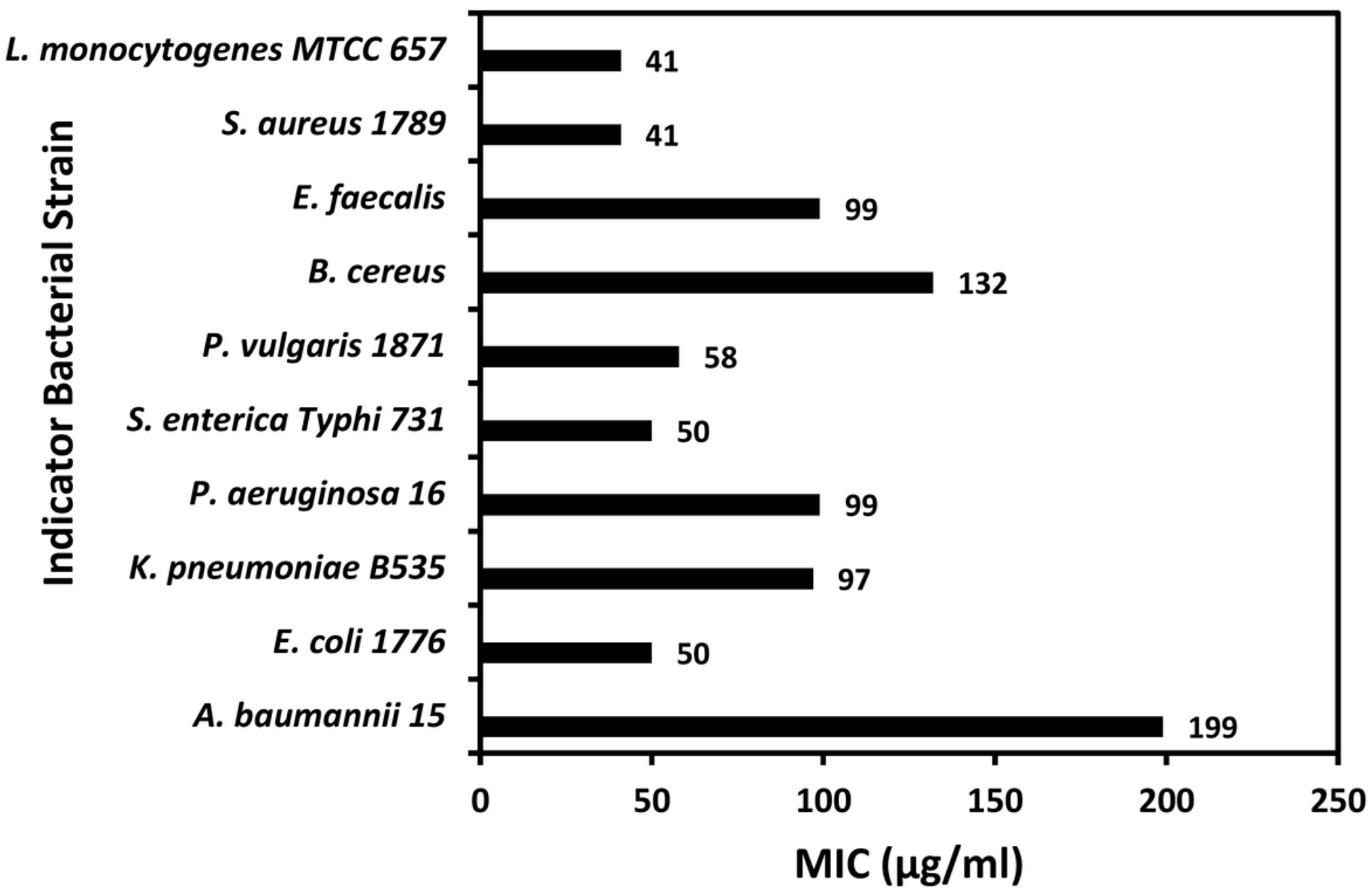

Figure 4

Minimum inhibitory concentration (MIC) values of L. fermentum LMEM22 bacteriocin against indicator bacterial strains. 